http://dx.doi.org/10.4314/jae.v16i1.8

\title{
Fishers' Adaptation to Climate Change in the Jebba Lake Basin, Nigeria
}

\author{
Nwabeze, G. O, Erie, A. P * and Erie, Gladys O.* \\ Socio Economics and Extension Services Division, National Institute for \\ Freshwater Fisheries Research (NIFFR), P.M.B 6006, New Bussa. Niger State. \\ Email: onyegodfrey@yahoo.com \\ * Dept of Agricultural Economics \& Extension, Ambrose Alli University, Ekpoma. \\ Edo State
}

\begin{abstract}
The paper provides an analysis of adaptation of fishers' households to climate change around Jebba Lake Basin, Nigeria. Fisheries of Jebba Lake Basin are presented as a system of dynamic trends, seasonality and shock. An analysis of livelihood diversification reveals that some households are more adaptable to environmental change than others. Fishers who have become overly specialised in fishing as sole livelihood activity are least able to adapt. The study thus recommends increased capabilities of fishers through formal enlightenment campaigns in respect of other livelihood portfolios outside fishing for better livelihood diversification.
\end{abstract}

Keywords: Adaptation, Fishers, Livelihood and Jebba Lake

\section{Introduction}

Increase in concentration of greenhouse gases in the atmosphere has repeatedly been argued for as major reasons for global climate change. IPCC (2007) confirmed global fluctuations in temperature, rainfall patterns, adverse extreme weather events, sea levels and other numerous environmental changes will occur. This has a significant effect on agriculture with impact on food and nutrition security. Fisheries subsector of agriculture is not left out in the overall negative impact of climate change. Fisheries contribute significantly to food security and livelihoods. As confirmed by FAO (2009a) report, fish provides essential nutrition for 3 billion people and at least $50 \%$ of animal protein and minerals to 400 million people from the poorest countries. According to WorldFish Center (2008), over 500 million people in developing countries depend, directly or indirectly, on fisheries and aquaculture for their livelihoods.

Nigeria has a number of important inland fisheries including those of Jebba Lake, Lake Chad, the River Niger, Lake Kainji, the Upper River Benue, Tiga Lake among others (Nwabeze, 2006). With an estimated total annual fish production of 511,000 
metric tonnes, the inland fisheries provide up to $85 \%$ of Nigeria's domestic fish production between 1991 and 2003 from estimated one million artisanal fishers fishing $125,470.82 \mathrm{~km}^{2}$ of inland water bodies scattered throughout the country and constitute artisanal fisheries communities (FDF, 2003; Fish for All Submit, 2005). The fisheries subsector are significant in the Nigerian economy contributing to total GDP in 2000 to 2004 at $1.2 \%, 1.6 \%, 1.7 \% 1.5 \%$ and $1.55 \%$ respectively, which translates to about $5 \%$ of agricultural GDP, this itself contributed between 30 and 35 percent in the same period (FAO, 2007).

Fishery production is directly affected by climate change through various processes. Ficke, Myrick and Hansen (2007) confirmed that fish production, growth and migration patterns are affected by temperature, rainfall and hydrobiology. Therefore changes in these parameters will alter pattern of fish species abundance and availability. Saltwater intrusion caused by rising sea levels may threaten freshwater fisheries while, at the same time, creating opportunities for catching and cultivating high-value brackish or marine species (WorldFish Center, 2007). Changes in precipitation will affect seasonal flooding patterns that influence inland fish production. While abundant wet season flooding may boost some inland fisheries production.

The sensitivities of capture fishery operation to various levels of climate change especially in relation to scale, intensity and environment in Nigeria including communities around Jebba Lake Basin showed that climate change may impact negatively on the fishers' livelihood with attendant serious socio-economic cost. The vulnerability of capture fishery investment to climate change is very high if appropriate adaptation mechanism is not developed.

In view of this, fishers' device adaptation strategies that are significant to achieving livelihood goals and aspirations. Identifying appropriate adaptation requires initial learning about the communities' indigenous capacities, knowledge and practices of how to cope with climate hazards (Reid and Huq, 2007). It is against this background that this study attempts an empirical validation of fishers' adaptation to climate change in fishing communities around Jebba Lake, Nigeria. The specific objectives of the study were to: determine areas of environmental vulnerability; examine adaptation strategies for climate change; and analyse fishers' livelihoods and adaptive capacity.

\section{Methodology}

The study was conducted in fishing communities around Jebba Lake Basin, Nigeria. The population comprised of all fishers' in fishing communities around Jebba Lake. The sample of the study was drawn from the population of artisanal fishers. The Jebba Lake is bounded by Niger and Kwara states. This informed the decision to use multi-stage sampling technique for the study. The first stage was the stratification of the communities around the Lake into 3 strata and selection of stratum one. Second was the identification of active fishing communities in stratum one and purposively selecting $5(30 \%)$ of total number of fishing villages within the stratum thus; Fakun, Bakoshi, Faransawa, Sabo Leaba and New Awuru. The third step was purposive selection of 18 percent of fishers in each of the selected 
fishing communities in the stratum. Respondents for the study were randomly selected thus in Fakun (52), Bakoshi (19), Faransawa (22), Sabo Leaba (16) and New Awuru (25) giving a total sample of 134 respondents out of 744 fishers (Table 1). A semi-structured questionnaire and participatory observation were used for data collection while descriptive statistical tools such as frequency count and percentage were used for data analyses.

\section{TABLE 1}

Sample of Artisanal Fishers by Stratum

\begin{tabular}{cccccc}
\hline Stratum & $\begin{array}{l}\text { Total No. of } \\
\text { Fishing } \\
\text { villages } \\
\text { in strata }\end{array}$ & $\begin{array}{l}\text { Total No. of } \\
\text { sampled fishing } \\
\text { villages by } \\
\text { stratum (30\%) }\end{array}$ & $\begin{array}{l}\text { Selected fishing } \\
\text { communities }\end{array}$ & $\begin{array}{c}\text { Total } \\
\text { number } \\
\text { of sample }\end{array}$ & $\begin{array}{l}\text { Total number } \\
\text { of sampled } \\
\text { fisher by } \\
\text { villages (18\%) }\end{array}$ \\
\hline 1 & 15 & 5 & Fakun & 289 & 52 \\
& & & Bakoshi & 105 & 19 \\
& & & Faransawa & 120 & 22 \\
& & & SabLeaba & 90 & 16 \\
Total & 15 & & New Awuru & 140 & 25 \\
\hline
\end{tabular}

\section{Measurement of Variables}

Variables for the study include selected socio-economic characteristics of fishers, namely, fishers' areas of environmental vulnerability, adaptations to climate change, analysis of fishers' livelihoods and adaptive capacity.

\section{Selected socio-economic characteristics}

The selected socio-economic characteristics considered for the study include; age, sex, level of education, marital status, household size, fishing experience and average annual income from fishing.

(i) Age: Respondents were asked to indicate their actual age in years

(ii) Sex: Respondents were asked to state their sex

(iii) Level of education: Respondents were asked to indicate from the list their level of education as no formal education, primary education and secondary education.

(iv) Marital status: Respondents were asked to state their marital status as single, married, divorced and widowed.

(v) Household size: Respondents were asked to indicate the number of dependents that feed from their pot.

(vi) Fishing experience: Respondents were asked to state the actual number of years they have been in fishing. 
(vii) Average annual income from fishing: Respondents were asked to state their income from fishing.

\section{Vulnerability analysis}

This was expressed in terms of environmental shocks, seasonality and trend within the livelihood framework as postulated by Carlos (2000).

\section{Adaptation strategies for climate change}

This was based on the identified adaptation strategies adopted for climate change. This was achieved by respondents rating on four point Likert scale of strongly agree $=4$, agree $=3$, disagree $=2$, and strongly disagree $=1$. The mean for each strategy was obtained by multiplying the point scale by the number of respondents in each point scale. Any adaptation strategy with a mean score equal to or above the mean of 2.5 was regarded as an important strategy and any mean score lower than 2.5 was not important.

\section{Analysis of fishers' livelihoods and adaptive capacity}

Fishers were asked to indicate the livelihoods they engaged in, the number of activities were computed along the mean annual income contribution from the combination of activities.

\section{Results and Discussion}

\section{Selected Socio-economic characteristic of respondents}

Respondents ages ranged from 19 to 71 , mean age was 45 (SD $=10.6$ ). Majority $(32.1 \%)$ of the respondents were $40-49$ years (Table 2 ). The result of the findings suggests that since about $62.6 \%$ of the respondents fall within the age range of less than 50 years, fishers in the study area are in their active age.

Fishing was practiced by both sexes in the study area with most (91.0\%) of fishers being male (Table 2). The low percentage of the female fishers in the study area may be as a result of their cultural limitation, energy demand of the profession. Although, the results showed the dominance of the artisanal fisheries sector by men, the contribution of the women folk in fishing activities cannot be underscored. According to Williams (2006), women mostly use traps and nets to catch fish in most fishing communities in Nigeria, and are also actively involved in fish processing and marketing (Uchola, 2000). Most of the respondents (82.8\%) were married. About $10 \%$ of them were single, $5.2 \%$ and $2.2 \%$ were widowed and divorced (separated) respectively (Table 2 ).

Majority (64.4\%) of the respondents had no formal education. About $26.9 \%$ and $9.0 \%$ had primary education and $3.0 \%$ secondary education (Table 2 ). This finding is therefore a disadvantage for the development and sustainability of the fishing profession as illiterate fishers are more unlikely to take advantage of technological innovations. Acquisition of formal western education had been found to relate highly to ability to reason well, increase effective participation in agricultural and rural development programmes (Ekong, 2003; Kuye, 2004). 
Respondents household size ranged from 3 to 12 persons with a mean of 9 persons $(S D=2.0)$. About $44 \%$ of the respondents' family size was 6 to 10 persons. About $37 \%$ had $6-8$ persons and $9.7 \%$ had more than 11 persons (Table 2). This was largely attributed to the extended family system in the area whereby parents, children and other relations live together as a household.

Collaborating the assertion are findings of 6-10 members in the northern part of Nigeria (Ikani, 2004).

Respondents experience in fishing activities ranged between 8 and 46 years with a mean experience of 28 years $(S D=2.0)$ (Table 2). The result reveal that majority $(34.3 \%)$ of the fishers had $31-40$ years experience in fishing. The years of practice of the fishers are an indication that fishing was popular, widely practiced and an age long occupation of the respondents. Evidently, these long years of fishing among the fishers could make them pro-active to extension training and contact on relevant climate change adaptation.

Respondents' average annual income from fishing activities ranged from $N 20,400$ to $N 192,000$ with a mean of $\mathrm{N} 81,123.11$ (SD = 1.8) (Table 2). About $62 \%$ of the respondents earned between $60,001-120,000,21.6 \%$ earned below $A 60,000$,

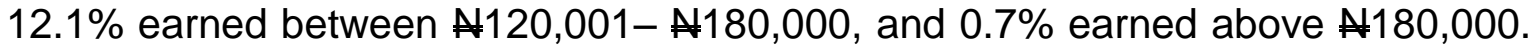
The mean annual fishing income of $181,123.11$ observed from the study implies low income earned from fishing activities. 
TABLE 2

Selected socio-economic characteristic of respondents

\begin{tabular}{|c|c|c|c|c|c|}
\hline Variable & Categories & Frequency & Percentage & Mean & $\begin{array}{l}\text { Standard } \\
\text { deviation }\end{array}$ \\
\hline \multirow{7}{*}{ Age } & $<20$ & 1 & 0.7 & & \\
\hline & $20-29$ & 13 & 9.7 & & \\
\hline & $30-39$ & 27 & 20.1 & & \\
\hline & $40-49$ & 43 & 32.1 & 45.0 & 10.6 \\
\hline & $50-59$ & 38 & 28.4 & & \\
\hline & $60-69$ & 9 & 6.7 & & \\
\hline & $70-79$ & 3 & 2.2 & & \\
\hline \multirow[t]{2}{*}{ Sex } & Male & 122 & 91.0 & & \\
\hline & Female & 12 & 9.0 & & \\
\hline \multirow{4}{*}{$\begin{array}{l}\text { Level of } \\
\text { education }\end{array}$} & No formal & 86 & 64.4 & & \\
\hline & education & 36 & 26.9 & & \\
\hline & $\begin{array}{l}\text { Primary } \\
\text { education }\end{array}$ & 12 & 9.0 & & \\
\hline & Secondary & 13 & 9.7 & & \\
\hline \multirow{5}{*}{$\begin{array}{l}\text { Marital } \\
\text { status }\end{array}$} & education & 111 & 82.8 & & \\
\hline & & 3 & 2.2 & & \\
\hline & $\begin{array}{l}\text { Single } \\
\text { Married }\end{array}$ & 7 & 5.2 & & \\
\hline & Divorced & 12 & 8.9 & & \\
\hline & Widowed & 50 & 37.2 & & \\
\hline \multirow{5}{*}{$\begin{array}{l}\text { Household } \\
\text { size }\end{array}$} & & 59 & 44.1 & 9.0 & 2.1 \\
\hline & $\begin{array}{l}3-5 \\
6-8\end{array}$ & 13 & 9.7 & & \\
\hline & $9-11$ & 8 & 6.0 & & \\
\hline & $>11$ & 25 & 18.7 & & \\
\hline & & 45 & 33.6 & 28.0 & 2.0 \\
\hline Fishing & $<11$ & 46 & 34.3 & & \\
\hline \multirow[t]{5}{*}{ experience } & $11-20$ & 10 & 7.4 & & \\
\hline & $\begin{array}{l}21-30 \\
31-40\end{array}$ & 30 & 21.6 & & \\
\hline & $>40$ & 85 & 62.0 & A87,811. & 1.8 \\
\hline & & 17 & 12.1 & 6 & \\
\hline & $<A 60,000$ & 1 & 0.7 & & \\
\hline Average & A60,001- & & & & \\
\hline annual & A120,000 & & & & \\
\hline income & N120,001- & & & & \\
\hline from & A180,000 & & & & \\
\hline fishing & $>\mathrm{N} 180,001$ & & & & \\
\hline
\end{tabular}




\section{Vulnerability analysis}

Vulnerability analysis highlights the environmental trend and shocks in Jebba Lake and its fisheries. The lake has its flow from Kainji Lake and is used primarily for hydro electricity generation. Most $(95 \%)$ of the respondents agreed that fisheries productivity of the lake is influenced by water volume and seasonality. The respondents grouped the season experienced into drawdown (February-August), white flood (September-October) and black Flood/Harmattan (October-January) periods. Discussants at Bakoshi and Faransawa indicated that at the onset of the drawdown months, the water spread area of the lake suddenly receded and became shallow. About $75 \%$ of the respondents opined that the onset of the raining season (May-June) marks a light relief as water level gradually increases with improved fish catch. This was hinged on the fact that the white flood is caused by the deposition of sediments from the Futa Djalon Mountain through Mali and Niger Republic into Kainji/Jebba Lake. The deluge of natural fish food during the white flood is of far greater impact in increasing fish abundance of the Lake. These seasonal tendencies have complicating results for the lake fishery, which is focused around important fish species caught [lates, cytharinus cytharus, clupeid, synodontis, oreochromis niloticus and momyrids]. Almost (90.0\%) of the fishers indicated that during the drawdown period in February/March catches were low whereas the white flood months in September/October stimulated extensive migration of large species of Tilapia and Lates from upstream resulting in high catches. Further analyses shows that white flood results in fish larvae recruitment and increased vulnerability of the Lake to pollution. Majority $(72 \%)$ of the respondents said that the temporarily closed ecosystems (blocked off for varied lengths of time) at the Kainji dam is an area of vulnerability. The period of closed and open phases is determined by the interaction on inflow into the Kainji dam for electricity generation. This is confirmed by FAO (2009b) report that hydropower dams and irrigation structures can improve water management and availability in the dry season, but they can also block fish migrations and reduce fish productivity. This was largely attributed to the removal of set gear by water waves. There was consensus among the fishers that increased water level is positively related to the productivity of the Lake and improved well-being of the fishers' households.

\section{Adaptation strategies for climate change}

Strategies adopted by fishers in coping with challenges of climate change effect are presented in Table 3. The significant adaptation strategies identified included increased diversification in non-fishing livelihood portfolios (mean $=3.07, \mathrm{SD}=$ 0.61 ), migration (mean $=2.92, S D=0.80$ ) and aquaculture practice (mean $=2.70$, $\mathrm{SD}=0.61$ ). This finding corroborates World Bank (2006) assertion that investment in sustainable aquaculture can buffer water use in agriculture while producing food and diversifying economic activities. Migration of fishers is primarily for the actualization of their livelihoods aspirations (Tafida, Nwabeze and Ayanda, 2011) 
TABLE 2

Adaptation strategies in coping with climate change effect

\begin{tabular}{lcc}
\hline Adaptation strategies & Mean & $\begin{array}{c}\text { Std. } \\
\text { Deviation }\end{array}$ \\
\hline Increased diversification in non-fishing portfolios & $3.07^{*}$ & 0.61 \\
Migration & $2,92^{*}$ & 0.80 \\
Aquaculture practices & $2.70^{*}$ & 0.61 \\
Adjustment of fishing programme period of plenty & 2.44 & 0.84 \\
fish catch & & \\
Use of specialized fishing gear & 2.39 & 0.70 \\
Increased fishing effort & 1.36 & 0.84 \\
\hline
\end{tabular}

Source: Field survey, $2011^{\star}$ Agreed (mean $\geq 2.50$ )

\section{Analysis of Fishers' Livelihoods and Adaptive Capacity}

Fishers' diversify into non-fishing livelihoods as alternative to vulnerability to declining fish catch due to climate change. Majority $(73.9 \%)$ of the respondents engaged in livestock keeping, crop farming $(64.9 \%)$ and petty trading $(36.6 \%)$. Few respondents $(8.2 \% ; 1.5 \%)$ were into skilled trade and fish farming, respectively (Fig 1). Nwabeze's (2006) study confirmed that fishers engaged in diverse livelihoods activities as coping mechanism and spreading of risk. Table 4 revealed that $71.6 \%(n=96)$ of the respondents were engaged in three income generating activities. About $17.9 \%$ and $10.4 \%$ were involved in two and four activities respectively. Fishers that were involved in four income generating activities had the highest mean annual income of $\$ 298,272.14$, three and two income generating activities had $\$ 254,154.16$ and $\$ 232,510.10$ respectively. Further analyses shows that increase in number of activity account for increase in mean annual income from all activities engaged in. Relating average annual income ( $\mathrm{N} 81,123.11)$ from fishing to that of other activities, it is evidenced that fishing contribute less half of the total income earned by the fishers with the least number of income generating activities. The result implies that some households are more adaptable to environmental change than others and fishers who have become overly specialised in fishing as sole livelihood activity are least able to adapt 


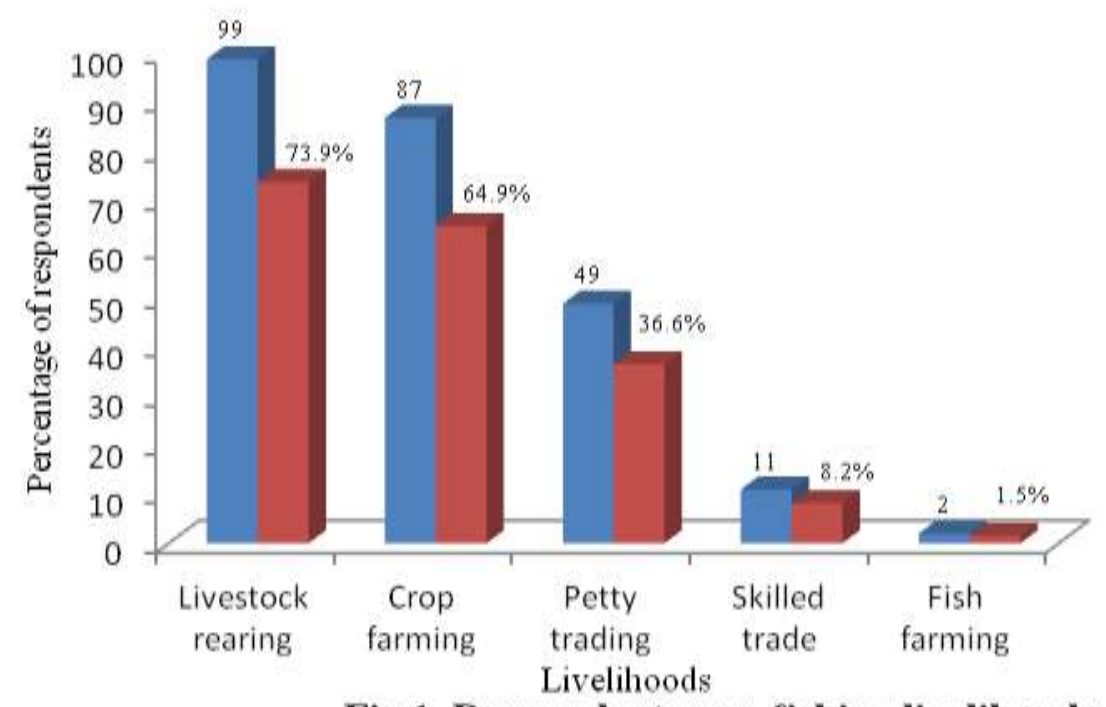

Fig 1. Respondents non-fishing livelihoods

TABLE 4

Mean annual income of fishers from diversified livelihood activities

\begin{tabular}{cccc} 
Number of activities & Frequency & Percentage & $\begin{array}{c}\text { Mean annual } \\
\text { income }\end{array}$ \\
\hline Two & 24 & 17.9 & N232,510.10 \\
Three & 96 & 71.6 & N254,154.16 \\
Four & 14 & 10.1 & N298,272.10 \\
\hline
\end{tabular}

Source: Field survey, 2011

\section{Conclusion and recommendation}

Diversification of livelihoods is a major driver to successful adaptation to climate change. Livelihood diversity helps ensure that, if one economic option temporarily closes, people can opt to other alternatives for making a living. Increased fishing effort as strategy adopted to cope with climate change effect could result in overfishing and consequently, collapse of the fisheries resources (WorldFish, 2007). Fishers in the study area are vulnerable to environmental trends and shocks. 
Based on the findings of the study, the following recommendations were made:

(i) Development policy should aim at improving livelihoods diversification that will help build fishers' adaptive capacity and strengthen resilience for climate change.

(ii) Policy must consider fishers in adaptation planning to ensure that adaptation measures in hydroelectricity projects, do not inadvertently undermine sustainability of fisheries

\section{References}

Carlos, P. (2000). Sustainable livelihood approach in inland fisheries. In: Programme PMEDP/SFLP. Cotonou, Republic of Benin, pp. 28, 33.

Ekong, E. E. (2003). An introduction to rural sociology. $2^{\text {nd }}(\mathrm{Ed})$, Dove Educational Publishers, Uyo, Akwa Ibom State, Nigeria, pp. 203-205, 323-343

FAO (2009a). The state of world fisheries and aquaculture, Rome, Italy.

FAO (2009b). Fisheries and aquaculture in a changing climate. Food and Agriculture Organization, Rome, Italy.

FAO (2007). Fish Country Profile, FAO. The Federal Republic of Nigeria. FID/CP/NIF. 24pp

FDF (2003). Fisheries development sub-sector. Paper presented at presidential forum, Abuja, pp. 1-11

Ficke, A. D, Myrick, C.A and Hansen, L. J (2007). Potential impacts of global climate change on freshwater fisheries. Reviews in Fish Biology and Fisheries, vol 17 (4), pp. 581-613.

Fish for All Summit (2005). Presentation of Nigeria's Fisheries Resources, Abuja, Nigeria 22-25 August 2005

Ikani, E. I. (2004). Level of Adoption of Cockerel Exchange Technology (CET) Among Poultry Farmers in Kaduna State. Ph.D. Dissertation, Department of Agricultural Economics and Rural Sociology, Ahmadu Bello University, Zaria.

IPCC (2007). Climate change: Synthesis report. Contribution of working groups I, II and III to the fourth assessment report of the Intergovernmental Panel on Climate Change. Pachauri RK,

Reisinger A (eds). Intergovernmental Panel on Climate Change, Geneva, Switzerland.

Kuye, O.O (2004). Determinant of effective participation of women in agriculture and rural development in Cross River. International Journal of Food and Agricultural Research, pp. 1-8. 
Reid, H. and Huq, S (2007). Adaptation to climate change: How we are set to cope with the impacts. International Institute for Environment and Development (IIED) Brief, June.

Nwabeze, G. O (2006). Factors related to changing livelihood strategies of artisanal fisherfolks in inland fishing communities of Delta State. M.Sc. Thesis, Department of Agricultural Extension and Rural Development, University of Ibadan, Ibadan.

Tafida, A.A, Nwabeze, G.O, Ayanda, J.O, Mohammed, A and John, C.T (2011). Examining risk factors in fishermen migration in Nigeria. Paper presented at FISON Conference, Federal University of Technonogy, Minna, Niger State, 20-25 $5^{\text {th }}$ November, 2011. (in press)

Uchola, E.B. (2000). An economic analysis of fish farming in Western Extension Zone of Lagos State. M. Sc. Thesis, Dept of Wildlife and Fisheries Management, University of Ibadan, Ibadan.

Williams, S. B. (2006). The socio-economic potentials of women in riverine smallscale fisheries in Nigeria. <Available from http//www.skk.uit.no> [Assessed $18^{\text {th }}$ July, 2006].

World Bank (2006). Aquaculture: Changing the face of the waters: Meeting the promise and challenge of sustainable aquaculture.

WorldFish Center (2008). The millennium development goals: Fishing for a future: Reducing poverty and hunger by improving fisheries and aquaculture.

WorldFish Center (2007). Fisheries and aquaculture can provide solutions to cope with climate change. Issues brief. WorldFish Center, Penang, Malaysia. 